\title{
Dispatches from Death Row, Texas
}

James V. Allridge III

\section{Dispatch I: The Big Move}

For those unaware, the escape of six prisoners in November, 1998, caused an investigation by the Texas Rangers and Governor George W. Bush's office. It resulted in the death row Work Capable Program at the Ellis Unit to be discontinued and a great debate began as to whether the older Ellis building was secure enough to house death row prisoners.

A proportion of the prisoners were moved in June and another group in November, 1999. These were supposed to be the "high risk" prisoners. After months of speculation over when or even if the remaining prisoners would be moved from the Ellis Unit to the Terrell Unit, we were all moved on March 2 and 3.

The evening prior to the move began with the officer coming by with sacks, giving each of us two and telling us we had two hours in which to pack what we could of our property. Unable to fit thirteen years of possessions into two sacks, many things such as books, catalogues, and less sentimental items had to be left behind.

The following morning, we were handcuffed and escorted from our cells. We were taken to the back lot where three buses awaited us, but not before we went through an assembly line of officers who stripped us naked for a search. We were then fitted with sleeveless jumpsuits (no boxers) and cloth slippers. I missed my pair of slippers so I had to walk barefoot.

I was led to another group of officers that first placed front handcuffs on me. I was then seated on the ground and shackled. A chain was looped through the handcuffs and the shackles, giving me only enough slack so that I had to walk stooped over. After being helped up by the officers, that is exactly what I had to do. I had to waddle to the bus, only being able to see what was a few feet in front of me because I could not stand erect.

As I came to the steps of the bus, I realized that I had to hop to make the first step of the stair, the officer only aiding those who were very old and not as dexterous as the rest of us. I made my way to the rear of the bus where others before me sat waiting with mixed emotions of fear, anger, anxiety, nearly hysterical ranting, and nervous laughter. Some just sat with quiet resolve to endure what they could do nothing to prevent. I was one of those. 
After all three buses were filled, we were on our way, escorted by the Department of Public Safety, Texas Rangers, various TDCJ officials, and, of course, the press. We had a helicopter escort as well. As we began our trek from Huntsville, roads were closed in our wake. The trip took about forty minutes. Most everything was a blur because I was hunched over, laden with chains. The most notable thing I do remember was the size of Lake Livingston and silently praying the driver would not go kamikaze into the water.

As we arrived at the new unit-our new home-I heard shouts, "Man, it's big!" or "It looks like one of those new schools," or "Whatda?" Personally, I saw no signs of life. No prisoners wiping their brows in the hot sun as they tended the landscape, like at Ellis. No sweaty prisoners stopping basketball mid-game to curiously watch the new arrivals. The motorcade of buses maneuvered through the compound, and we soon saw where everyone was-guards, anyway.

A check-in station had been erected for us under a tin canopy. As we disembarked from the buses, our chains were removed so we could finally stand. Handcuffs in place, we were taken through another procession, again stripped of our jumpsuits (apparently these belonged to Ellis Unit and had to be returned), given ill-fitting boxers and socks. When our names were verified on a roster, we were quickly escorted to our new cells. As the door slammed behind me, it only took me a couple of seconds to take in the six and a half by ten-foot cell. It contained a bunk with shelf space underneath, a desk with one other shelf above it, and a combination sink and toilet. A small slit of a window (three by thirty-six inches) gave me the only ray of sunshine I would see for some time.

I was jarred from my stupor as the officer told me to turn around, squat and thrust my handcuffed hands through the beanslot (a slot in the door used to slide our trays through, which in the old days usually contained beans and bread; hence, "beanslot") so he could uncuff me. I stood there in my baggy boxers and socks, waiting for someone to give me a set of clothes or a jumpsuit, but no one came. I watched as others were brought in to their respective cells, trying to see where they were putting my friends. It was quiet. I suppose everyone was coming to terms with the new situation.

Not much has changed since that day. We are confined to our cells twenty-three hours a day. We have the opportunity to come out for recreation for one hour, but most do not even bother because you can only go to the dayroom or what they call "outside rec" by yourself. There is no physical 
contact with another prisoner. "Outside rec" is basically a dayroom with the roof off. You can only look up and see the sky.

The plexiglass covering the front of the cells (to prevent urine and feces from being thrown on officers) prevents any meaningful conversations. I am on a less restrictive pod where the doors are not so covered so I can carry on conversations to a certain degree. But that is as little as the restrictions get. I am still confined twenty-three hours a day. There is no television. No group recreation. No work program. The arts and crafts program is still suspended, and to top it off, my word processor was damaged during the move (which they refuse to take responsibility for) so writing for publication is out for now.

Most of you who know me pretty well know that I am not a complainer. I have tried to answer most of your questions because this is all new to me and to you, and many of you wanted to know how I was coping and what it is like here. I do stick to my original statement that humans were not meant to live like this.

Sadly, there have been two attempted suicides. Men are becoming recluses and introverts. Some sleep the majority of the time, being listless and cranky. Not everyone has the ability or means to find things in their cell or occupy their time as I do. And I do thank those who have sent books, got me the book club membership and sent puzzles. And I am really grateful to the two who sent money to the Trust Fund because the food here sucks!

But, you know me, I deal with what I got and make the best of it. I am still the eternal optimist and an optimist is one who makes the best of it when he gets the worst of it. I have the unique opportunity to get more done now than I had before because of all the distraction. Without television I read more; I have probably read more books in these three months than I have in three years. Others are taking advantage of this time as well. I have had the privilege to help some of the younger guys (and they are youngsome are only nineteen or twenty) promote their art, writings, and set up defense funds.

Of course, the main thing is I have been able to spend more time with those of you to whom I write on a regular basis. You probably get tired of my long, handwritten letters, but your friendship and love is invaluable. You are my therapists (please don't bill me!) and I am grateful to you all. Thanks.

Also, some of your letters may have been returned and not forwarded from Ellis, and some I have not written since the move. For clarification, please write to: 
James V. Allridge III \#870

Charles T. Terrell Unit

12002 F.M. 350 South

Livingston, Texas 77351

I hope to have an e-mail account available soon, so in cases where those of you overseas need to contact me quickly, you will be able to. I also hope to have a website set up as well. Anyone want to be my Web Master?

\section{Dispatch II: The Killing Machine}

When my brother, Ronald Keith Allridge, was executed on June 8, 1995, it triggered a medley of emotions within me. Some I never even fully understood, or took the time to come to terms with.

Ronnie was special to me for many reasons, but he was special to many here within the Death Row community because he was the first person most of us knew who refused to come out of the death watch cell willingly. He said that he was not going to walk to his death. And he did not. He wanted the authorities to know that the taking of someone's life against their will is murder, no matter how you try to justify it. But not many noticed Ronnie's act of defiance.

Five years and two weeks to the day (June 22, 2000), a similar scene took place. But this time, the world was watching. This time it was Gary ("G.G.") Graham, who came to be known as Shaka Sankofa.

I have listened to accounts on the radio and I have read accounts in the newspaper and, of course, I have lived in this environment with him. $\mathrm{He}$ fought when they came to take him from his regular cell and place him in a Death Watch Cell. They tricked him coming out of the Visiting Room, but he fought when they came to take him to the Walls Unit to await execution. He fought when they came to strap him to the gurney.

I listened to his Spiritual Advisor, Minister Robert Muhammad, on the radio the Sunday following G.G.'s execution. Minister Muhammad said that G.G. was not just strapped but handcuffed to the gurney. They had his head restrained with black Velcro because, apparently, even after they had subdued his with handcuffs he still attempted to bite them. It was said that a sheet covered his body and the paper gown that they had him clothed in was 
visibly torn and raggedy-apparently also from the struggle. I can imagine that he fought as they physically pinned him down in further humiliation to strip him of his prison attire, donning him with a diaper so that as his body died and his bowels and kidneys released themselves they would not have the mess to clean up, which would distort the image of their clean, sanitary and humane killing machine.

Shaka was a man who fought. He fought until he could not fight anymore. He fought. He fought, not so much that his life be spared but he fought for justice to be done in his instance. I can honestly say that I remember G.G. lastly as being a fighter. But I had never had the pleasure of meeting Shaka Sankofa, that man that G.G. had become. It had been over twelve years since we had been around one another, but I admired him from afar. I admired all the things that he did, not just for himself but for everyone on Death Row. I admired him for the leadership role that he took upon himself when few others would. Not to be a star, but to bring attention and focus to this increasingly dire situation with the death penalty in Texas.

As he lay there dying, he once again professed his innocence and then quickly turned his attention to us, those remaining. He urged that we continue to fight to see a moratorium put in place.

I have to tell you, I am so tired of sitting here watching people that I have come to know and love steadily being killed off, one by one. Some deaths just affect you more. My brother's death, as I said, touched me in ways that I yet have to deal with. The execution of one of my best friends, Glen McGinnis, had a profound effect on me. Now G.G. It has to stop. Plain and simple.

My fight has mostly been about saving my life. That is because I believe you have to first help yourself before you can help someone else. And I will continue to do my individual projects even though it gets daunting at times. I think about G.G.'s case. This is a man who had strong claims of innocence. He had numerous political, abolitionist, social, religious, legal, and media ties but was still executed by this merciless system. If that amount of backing and support could not save his life, then what possible chance do the rest of us have under the current system? The system has to change.

A moratorium will affect all of Death Row, so I am asking for your help. At this point, I do not really know what I want to do, but I know I am going to do something. I want your help, your ideas and your support. Get with me. We have to do something, and now. More will probably have been executed by the time you read this. This is, indeed, a "State of Emergency." 
James Allridge III is on death row in Texas, and is a former contributor to the JPP. His pencil drawing "The Piano Wave" was the cover art for Volume 6, No. 1 (1995) and "Wolf Woman" was the cover art for Volume 8, Nos. 1 and 2. James' prisoner number is 870 and he can be contacted at the Charles T. Terrell Unit, 12002 F.M. 350 South, Livingston, Texas 77351, U.S.A. 